\title{
VARIATION OF THE BACTERIAL COMMUNITIES IN THE RHIZOSPHERE OF THREE SPECIES OF THE GENUS TAGETES (MARIGOLD) OVER TIME
}

\author{
LÓPEZ-LÓPEZ, E. ${ }^{1}$ - MEJÍA, O. ${ }^{2}$ - MERCADO-FloRES, Y. ${ }^{1}$ - TÉLlEZ-JURADO, A. ${ }^{1}$ - ANDUCHO- \\ REYES, M. A. ${ }^{1^{*}}$ \\ ${ }^{1}$ Lab. de Microbiología Molecular, Universidad Politécnica de Pachuca, carretera Pachuca \\ Cd. Sahagún, km. 20, Rancho Luna, Ex Hacienda de Sta. Bárbara, Zempoala, Hidalgo, C.P. 43830, \\ México (tel/fax:+52-771-547-7510) \\ ${ }^{2}$ Lab. de Variación Biológica y Evolución, Departamento de Zoología, E.N.C.B. Instituto \\ Politécnico Nacional, Prol. de Carpio y Plan de Ayala S/N Col. Santo Tomas, Delegación Miguel \\ Hidalgo, Ciudad de México, C.P. 11340, México (tel: +52-555-729-6300) \\ *Corresponding author \\ e-mail:anducho@upp.edu.mx
}

(Received 24 $4^{\text {th }}$ May 2017; accepted $11^{\text {th }}$ Aug 2017)

\begin{abstract}
In the present study, the molecular profiles of rhizospheric bacterial communities of Tagetes terniflora, T. remotiflora and T. coronopifolia were analyzed at different times using soil samples under greenhouse conditions. To this end, samples spanning were obtained at 3, 30, 60 and 90 days. Metagenomic DNA was extracted and the 16S rDNA genes were amplified by PCR-touchdown to reduces the formation of spurious by-products. The amplified fragments were run through Denaturing Gradient Gel Electrophoresis (DGGE) to obtain their molecular profiles. Shannon's index showed a decline of bacterial diversity over time. Also, to visualize spatial proximities by species, a non-metric MDS ordination was conducted, generating a stress value of 0.179 . A one way-ANOSIM showed significant differences between T. terniflora and $T$. coronopifolia $(\mathrm{R}=0.78, \mathrm{p}<0.05)$, and between $T$. remotiflora and $T$. coronopifolia $(\mathrm{R}=0.791, \mathrm{p}<0.05)$. Sequencing of some DGGE profiles bands showed that Pseudomonas was present at 3,30 and 60 days in all species of Tagetes, while Chloroflexus and Delftia were present at 3 and 60 days in T. remotiflora and T. coronopifolia, respectively. The study demonstrated that the beneficial populations were positively selected and sample time and species affect the dynamic succession in the rhizobacteria communities.
\end{abstract}

Keywords: $n M D S, D G G E, 16 S$ rRNA, V3 hypervariable region, Bray-Curtis similarity index

\section{Introduction}

The term microbial diversity is used to explain the composition, complexity and structure of microbial communities in natural systems. In ecosystems, such as soil and rhizosphere, diverse microbial consortia play an important role in biogeochemical cycles, decomposition and mineralization of organic matter, as well as the formation and maintenance of edaphic structure that confer soil quality (Johnson et al., 2003; Kirk et al., 2004; Ranjard et al., 2010). Besides, the microbial communities influence the nutrition and health of plants through the processes of mineral solubilization, hormone production, and nitrogen fixation at the same time that also antagonizing pathogenic microorganisms (Petersen et al., 1996; Pinton et al., 2001; Prosser, 2002; Nannipieri et al., 2003; Saharan et al., 2011). 
In rhizospheric environments, which are considered a complex example of ecological equilibrium between microbiome and plant roots, most of the environmental changes that occur are attributed to organic substances exuded by the roots, which constitute a nutrient source for microorganisms (Hardoim et al., 2015; Chiarini et al., 1994; Rovira, 1965). However, the composition of rhizospheric exudates is affected by the stage of plant development (Hamlen et al., 1972), which can lead to the selection of specific bacterial genotypes (Picard et al., 2000) that may influence changes in the structure, patterns and activities of rhizobacterial communities (Di Cello et al., 1997; Hamlen et al., 1972; Chen et al., 2014) as has been documented in several microbial communities through an habitat filtering or by interspecific competition (Pontarp et al., 2012; Crits-Cristoph et al., 2013; Zelezniak et al., 2015; Centeno et al., 2016).

Actually, there is a growing interest in the allelopathic properties of plants of the genus Tagetes due that, the alternated cultivation of these plants with economically-important crops such as tomato, potato, mulberry, strawberry, soybean, pineapple, cabbage, cauliflower, lettuce, taro and carrot had been successful in the control of plagues (Hooks et al., 2010) mainly by the allelochemical substances produced in flowers, leaves, stems and roots (Weidenhamer et al., 2009). Experimental evidence suggests that certain allelochemical substances, such as $\alpha$-terthienyles, produce oxygen-free radicals that can significantly reduce populations of root knot nematodes, insects, fungi, bacteria, and some viruses (Tereschuk et al., 1997; Nivsarkar et al., 2001; Tomova et al., 2005). Nevertheless, little is known about the changes in the composition of bacterial communities in the rhizosphere over time. Hence, the aim of this study was to analyze the antagonistic effect of three species of the genus Tagetes on changes in rhizosphere bacterial diversity and community structure at different growth stages. To this end, molecular profiles of the V3 hypervariable region of the $16 \mathrm{~S}$ rRNA gene were obtained using the Denaturalizing Gradient Gel Electrophoresis technique (DGGE) approach.

\section{Materials and Methods}

\section{Soil samples}

Soil samples were collected in La Vega de Metztitlán region in the state of Hidalgo, Mexico, a zone considered the main agricultural area in the Barranca de Metztitlán Biosphere Reserve located at 20 42' 12"; $20^{\circ} 28^{\prime}$ '04" $\mathrm{N}$ and $98^{\circ} 53$ '20"; $98^{\circ} 40^{\prime} 21^{\prime \prime} \mathrm{W}$, at a mean altitude of 1,270 m (4,167 ft.) above sea level (Guzmán et al., 2008). Ten samples were taken randomly in a 5-hectare area (12.4 acres) of agricultural fields planted with chili peppers near the locality of Tres Cruces. First, the upper layer of soil was removed $(\approx 5 \mathrm{~cm})$, then, approximately $50 \mathrm{~kg}$ of soil were collected, placed in sterile polyethylene bags, and sealed with elastic bands. After it, in the laboratory, the ten samples were mixed to yield one composite sample, which placed in polypropylene bags in $2 \mathrm{~kg}$ quantities and autoclaved for 45 minutes at $121^{\circ} \mathrm{C}$, this process was repeated three times with 24 hours of difference. 


\section{Tagetes crop}

To establish the crop of Tagetes plants under greenhouse conditions, seeds of three species were used: $T$. terniflora, $T$. remotiflora and $T$. coronopifolia, all provided by Dr. Miguel Ángel Serrato Cruz of the Department of Plant Science at the Universidad Autónoma de Chapingo, Mexico. Planting the three Tagetes species was conducted as follows: 10-12 seeds were germinated in glass Petri dishes using filter paper moistened with distilled water as support. To maintain humidity, the Petri dishes were placed on a plastic tray $(20 \times 15 \times 5 \mathrm{~cm})$ and covered with cellophane plastic that contained moist paper towels. Under these conditions, the seeds were exposed to solar light and environmental temperature until germination. The distilled water was changed every $24 \mathrm{~h}$ by adding a fresh volume of $10 \mathrm{~mL}$ to prevent the seeds from rotting. At 8-14 days after germination, 10 seedlings of each species were transplanted into plastic boxes $(72 \times 42 \times 66 \mathrm{~cm})$ containing sterile composite soil sample to $3 / 4$ of their capacity. The seedlings were separated by $15 \mathrm{~cm}$ to obtain better development. Finally, a control with no plants was established.

\section{Samples of rhizospheric soil}

To evaluate changes in the composition of the bacterial community, sampling of the rhizospheric soils was performed at 3, 30, 60 and 90 days after transplanting the seedlings. For each specie and stage, was collected and chosen at random, a unique whole plant with adhering soil. The rhizosphere soil was obtained removing the loose soil by careful shaking, after which tightly-adhering soil was sampled from the root surfaces of each plant, we obtained three replicates of approximately $1.5 \mathrm{~g}$ of rhizospheric soil, which was placed in 2-ml polypropylene tubes and stored at $4^{\circ} \mathrm{C}$.

The physicochemical analysis of the rhizospheric soil collected in La Vega (Metztitlán) was conducted using the Motte Turf Lab Deluxe kit (model TL-2 ${ }^{\circledR}$, Cáceres, Spain) following the protocol provided by the supplier. Analysis consisted in determining nitrogen $(\mathrm{N})$, total phosphorus $\left(\mathrm{P}_{\text {tot }}\right)$, potassium $(\mathrm{K})$ and iron $(\mathrm{Fe})$ content, $\mathrm{pH}$, and soil texture. Determination of the soil texture type was based on data obtained for the percentages of clay, sand and loam, using a triangle of soil texture in accordance with the Official Mexican Norm NOM-021-RECNAT-2000.

\section{Extraction of nucleic acids}

Extraction of metagenomic DNA from the rhizospheric soil and controls was carried out using the protocol described by Cullen and Hirsch (1998), the procedure basically was lysis of indigenous soil microorganisms using alkaline-SDS buffer in a bead-beater. Purification of the extracted metagenomic DNA was performed with the commercial Zymo Research ZR Soil Microbe DNA MiniPrep ${ }^{\mathrm{TM}}$ kit (Zymo Research Corp, Irvine, CA, U.S.A.), following the manufacturer's instructions. The quality of the DNA was observed in agarose gels at $1 \%$ with TAE $1 \mathrm{X}$ regulator.

\section{DGGE-PCR}

DGGE-PCR amplification of the V3 hypervariable region of the bacterial 16S rRNA gene (193 bp) from the extracted and purified rhizospheric DNA was conducted with the 
universal oligonucleotides $P 3$ (5'- CCT ACG GGA GGC AGC AG-3'), and P2 (5'-ATT ACC GCG GCT GG-3'). A GC clamp of 40 nucleotides (5'-CGC CCG CGC GCG GGC GGG GCG GGG GCA CGG GGG G-3') was added to the forward oligonucleotide $P 3$ at position 5' (Muyzer et al., 1993). Touchdown PCR was performed in a total reaction volume of $100 \mu \mathrm{l}$. The concentrations of each component of the reaction mix were $5 \mathrm{ng}$ of DNA, 1X PCR buffer (20 mM Tris- $\mathrm{HCl} \mathrm{pH} 8.0$ and $50 \mathrm{mM} \mathrm{KCl}$ ), $2.5 \mathrm{mM}$ of $\mathrm{MgCl}_{2}, 250.0$ $\mathrm{mM}$ of each dNTP, $0.2 \mathrm{mM}$ of each initiator, $0.25 \mathrm{OR} / \mu 1$ of Taq DNA polymerase (Invitrogen $^{\circledR}$ ) and $250 \mathrm{ng} / \mu \mathrm{l}$ of BSA $\left(\right.$ Amresco $^{\circledR}$ ). The amplification conditions of Touchdown PCR were conducted with an initial cycle at $95^{\circ} \mathrm{C}$ for $10 \mathrm{~min}$. Next, the alignment temperature was reduced from $65^{\circ} \mathrm{C}$ to $50^{\circ} \mathrm{C}$ in intervals of $1^{\circ} \mathrm{C}$ during 15 cycles. An additional 20 cycles were run at an alignment temperature of $50^{\circ} \mathrm{C}$. Each cycle involved a denaturalizing temperature of $94^{\circ} \mathrm{C}$ for $1 \mathrm{~min}$ and an extension temperature of $72^{\circ} \mathrm{C}$ for $90 \mathrm{~s}$, followed by a final extension at $72^{\circ} \mathrm{C}$ for $5 \mathrm{~min}$.

Denaturalizing Gradient Gel Electrophoresis (DGGE) was performed following the methodology described by Muyzer et al., (1993). Polyacrylamide gels at $7 \%$ were prepared $(16 \times$ $16 \mathrm{~cm}$ ) with a chemical denaturalizing gradient of $0-80 \%$ utilizing a urea solution at $5.6 \mathrm{M}$ and formamide at 32\% (Sigma-Aldrich, St. Louis, MO, U.S.A.). $20 \mu \mathrm{l}$ of the Touchdown PCR product were added to each well of the gel, and then run them in an electrophoresis chamber (DGGE-2001, CBS Scientific, San Diego, CA, U.S.A.) that contained TAE 0.5X regulator. Electrophoresis was pre-run for $20 \mathrm{~min}$ at $200 \mathrm{~V}$ and then for $15 \mathrm{~h}$ at $60^{\circ} \mathrm{C}$ and $70 \mathrm{~V}$. Visualization of the DNA bands was carried out using silver stain from the commercial PageSilver ${ }^{\mathrm{TM}}$ Silver Staining Kit (Fermentas, Glen Burnie, Maryland, U.S.A.).

\section{DNA sequencing and phylogenetic reconstruction}

The amplified and purified fragments from the V3 region of the 16S rDNA gene were sequenced in both senses using DGGE-PCR initiators (but without the GC clamp) in an automatic 3130 Applied Biosystems ${ }^{\circledR}$ Genetic Analyzer sequencer with 4 capillaries (Foster City, CA, U.S.A.) at the Department of Seed Production at the Colegio de Posgraduados Chapingo. Once the DNA sequences were obtained, they were compared using the BLAST program (http://blast.ncbi.nlm.nih.gov/Blast.cgi) in order to identify similar sequences in the database of nucleotide deposited at the National Center for Biotechnology Information (NCBI). The sequences were edited manually with the help of the BioEdit program V.7.2.5 (http://www.mbio.ncsu.edu/bioedit/bioedit.html), and aligned using the program Clustal X V.2.1 (Thompson et al., 1997). The phylogenetic relationships of the sequences were determined by maximum likelihood analysis (ML) using the PhyML program (http://atgc.lirmm.fr/phyml/) (Guindon et al., 2010). The optimal model of the evolution of our sequence data was obtained using the Akaike Information Criterion (AIC) with Modeltest program V.3.7 (Posada and Crandall, 1998). The support values for each node were estimated using 5,000 bootstrap replicates.

\section{Statistical and DGGE analyses}

DGGE gel banding patterns were examined using the 1D gel electrophoresis image analysis software GelAnalyzer (http://www.gelanalyzer.com/index.html). Each band was coded as present (1) or absent (0), and described by its position in the banding profiles. 
Shannon's diversity indexes were estimated for each profile. Also, binary data were transformed mathematically for normalization by the equation $x^{6}=\log 10(x+1)$ before applying the Bray-Curtis index (Legendre and Legendre, 2012).

The PCR-DGGE-generated banding patterns of the soil samples obtained from the rhizosphere of the three Tagetes species and the control at different times were analyzed using a clustering algorithm from the Bray-Curtis index. Additionally, PERMANOVA (Permutational Multivariate Analysis of Variance Using Distance Matrices) with 5000 permutations was performed to test for significant differences between species and development stage in the bacterial community of the rhizosphere. Cluster analysis and dendrogram generation were carried out using PAST software package (PAleontological STatistics) v.3.0. (Hammer et al., 2001).

To state the changes in the bacterial community composition, a one-way ANOSIM analysis with 999 permutations was performed using Tagetes species and sampling time as the explanatory variables. This analysis allowed us to evaluate the null hypothesis, $H_{0}$, which indicated that there were no significant differences in the structure of the bacterial communities of the three species of Tagetes. For each ANOSIM test, we calculated separately the statistical Global $\mathrm{R}$ at a significance level of $p<0.05$ to reject the null hypothesis. Also, species turnover bacterial communities were estimated using the Whittaker Beta Diversity index.

Also, a non-metric multidimensional scaling analysis (nMDS) was performed with 999 bootstraps to avoid minimal local (Legendre and Legendre, 2012). Both multivariate (ANOSIM and nMDS) and beta-diversity analyses were performed using the Bray-Curtis similarity index with the aforementioned PAST software package.

\section{Results}

\section{Soil analysis}

The physicochemical analysis of the composite soil collected in La Vega de Metztitlán, and used to grow the Tagetes plants, was found to contain the following quantities: $\mathrm{NO}_{3}-\mathrm{N}$ $=5.60 \mathrm{~g} / \mathrm{m}^{2} ; \mathrm{P}_{\text {tot }}=0.56 \mathrm{~g} / \mathrm{m}^{2} ; \mathrm{K}=17.933 \mathrm{~g} / \mathrm{m}^{2} ;$ and $\mathrm{Fe}=1.5 \mathrm{ppm}$; while $\mathrm{pH}$ was 7.0 . The analysis of soil texture demonstrated that it was made up of $53.3 \%$ sand, $16.7 \%$ loam, and $30.0 \%$ clay, and so may be considered of the sandy clay loam type.

\section{DGGE patterns and bacterial diversity}

Nine samples obtained from the rhizospheres soils of the three Tagetes species at different times, plus three control samples, were subjected to electrophoresis in two acrylamide gels under denaturing conditions. Analysis of the gels using GelAnalyzer software (V. 2010a, freeware; Istvan Lazar) showed profiles that were both complex and diverse and that together made it possible to identify a total of 101 bands. The relative intensity or crude volume of each band was calculated after staining with $\mathrm{AgNO}_{3}$, which produced values in the range of $0.43-7.8 \%$. The average number of bands per sample was 37.1. Specifically, for the four sampling times in T. terniflora, the average number of bands was 43.6, while the averages calculated for $T$. remotiflora and $T$. coronopifolia were 35.4 and 32.4 bands, respectively. The number of bands in the molecular profiles for each time 
and species decreased as time increased. Thus, the analysis of triplicate gels showed that at 3 days $T$. terniflora presented, on average, $50 \pm 4.3$, at 30 days $52 \pm 1.7$, at 60 days $39 \pm$ 4.7 , and at 90 days $35 \pm 6.0$ bands; T. remotiflora at 3 days $42 \pm 4.3$, at 30 days $31 \pm 2.7$, at 60 days $34 \pm 6.0$, and at 90 days $36 \pm 6.0$ bands; $T$. coronopifolia at 3 days $39 \pm 4.0$, at 30 days $34 \pm 4.0$, at 60 days $29 \pm 4.3$, and at 90 days $29 \pm 5.0$ bands; and controls at 3 days \pm 2.433 , at 30 days $32 \pm 2.4$, at 60 days $29 \pm 1.4$, and at 90 days $23 \pm 1.4$ bands.

Due to the allelopathic properties of the roots of Tagetes terniflora, T. remotiflora and $T$. coronopifolia, an analysis of variation of rhizosphere bacterial communities in soil was carried out using the molecular profiles generated by DGGE at 3, 30, 60 and 90 days of growth (Figure 1A). The DGGE profiles were reproducible in triplicate, regardless of the DNA extraction process. Profiles were analyzed utilizing a criterion of coincident bands, which allows the construction of dendrograms and calculations of diversity indexes. The dendrogram shown in Figure $1 B$ represents the similarity of the relationships among the molecular profiles obtained from the samples of rhizospheric soils at the different times of development for the three species of Tagetes. This dendrogram presents a cophenetic correlation coefficient of 0.9054, using a Bray-Curtis similarity measure and 5000 replicates. This analysis made it possible to recover two main clusters, one that included the control and $T$. coronipifolia, and a second with $T$. terniflora and T. remotiflora. In the main cluster, all samples from the same treatment were recovered jointly. In the control, the most similar communities were found between the samples collected at time 3 and 30 (similarity above $96 \%$ ), while the sample collected at time 90 showed the greatest difference, with a similarity of just $80 \%$. The similarity values calculated for the $T$. coronipifolia samples collected at time 3 and 30 and times 60 and 90 were quite close to each other $(\approx 60 \%)$. For T. terniflora, the most similar communities were found between times 3 and $30(\approx 70 \%)$, while the sample taken at time 90 differed most markedly $(\approx 46 \%)$. Finally, for $T$. remotiflora, the most similar communities were found between times 30 and $60(\approx 56 \%)$, and the most different sample was the initial community sampled at time $3(\approx 46 \%)$.

Whittaker beta diversity $\left(\beta_{\mathrm{w}}\right)$ indexes were estimated to detect changes in bacterial composition among species and over time. All estimated values were above zero, even in the control sample over time. Beta diversity values ranged from $\beta_{\mathrm{w}}=0.014$ in the control sample between days 3 and 30 to $\beta_{\mathrm{w}}=0.827$ between the control sample at day 90 and $T$. remotiflora at day 30 . The low beta diversity values correspond to the control treatment at the different times.

These Whittaker global beta diversity values show that $T$. coronopifolia had the highest rate of species turnover at $\mathrm{G} \beta_{\mathrm{w}}=1.100$, while $T$. terniflora and $T$. remotiflora showed values of $\mathrm{G} \beta_{\mathrm{w}}=0.847$ and $\mathrm{G} \beta_{\mathrm{w}}=1.040$, respectively. The Mantel test using 9999 permutations suggests that regardless of the changes in bacterial species during the sampling times for each species, the relations between beta diversity and time were statistically-distinct from zero $(r=0.0049, p=0.4312)$.

As a means of measuring alpha diversity, we estimated Shannon's diversity indexes for the electrophoretic profiles generated by the rhizosphere of T. terniflora, T. remotiflora and T. coronopifolia (Table 1). The indexes of biodiversity estimated for T. terniflora presented a value of 3,573 on day 3, though this decreased at 30 and 60 days to values of 3,345 and 3,445 , respectively. However, at day 90 the value increased to 3,468. In the cases of $T$. 
remotiflora and $T$. coronopifolia, observations discerned a downward tendency in the estimated diversity indexes. The boxplot graphs in Figure 2 show the diversity of the molecular bands in the DGGE profiles. Of the three species of Tagetes used, the greatest band diversity was observed in T. coronopifolia.
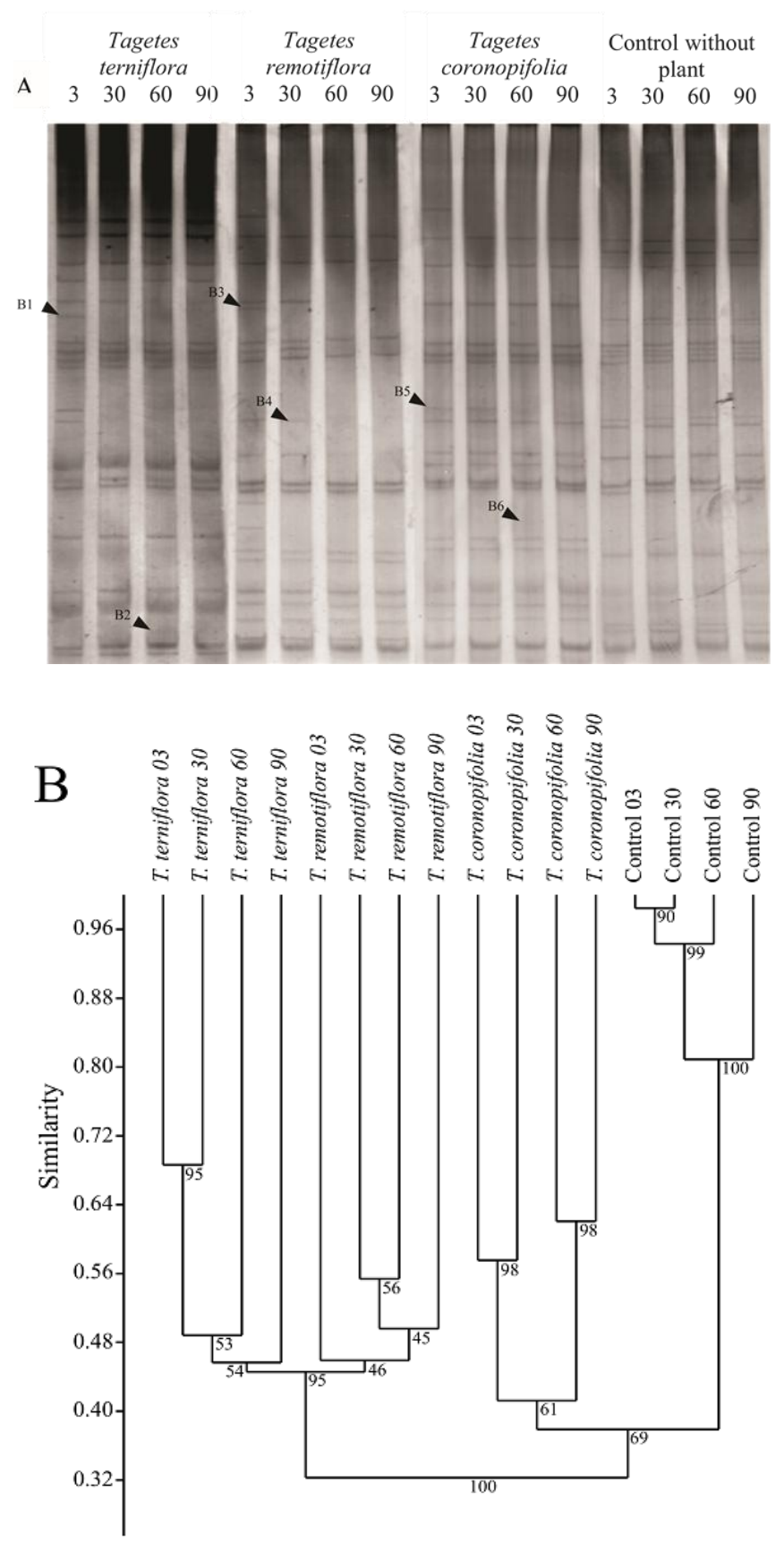

Figure 1. A. Denaturalizing Gradient Gel Electrophoresis (DGGE) of the molecular profiles of the bacterial communities of rhizospheric soils obtained from three species of Tagetes and controls;

B. Dendrogram constructed on the basis of the DGGE molecular profiles, utilizing Jaccard's similarity coefficient, grouped by Neighbor-Joining 
Table 1. Shannon's diversity indexes ${ }^{l}$

\begin{tabular}{|c|c|c|c|c|}
\hline \multirow{2}{*}{ Sample } & \multicolumn{4}{|c|}{ Shannon's Diversity Index ${ }^{1}$} \\
\hline & 3 days & 30 days & 60 days & 90 days \\
\hline $\begin{array}{l}\text { Rhizospheric soil from } \\
\text { Tagetes remotiflora }\end{array}$ & $3.738(0.043)^{2}$ & $3.434(0.043)$ & $3.526(0.061)$ & $3.584(0.053)$ \\
\hline $\begin{array}{l}\text { Rhizospheric soil from } \\
\text { Tagetes terniflora }\end{array}$ & $3.912(0.043)$ & $3.951(0.017)$ & $3.664(0.0)$ & $3.555(0.0)$ \\
\hline $\begin{array}{l}\text { Rhizospheric soil from } \\
\text { Tagetes coronopifolia }\end{array}$ & $3.664(0.031)$ & $3.526(0.041)$ & $3.367(0.0)$ & $3.367(0.050)$ \\
\hline $\begin{array}{l}\text { Non-rhizospheric soil } \\
\text { control }\end{array}$ & $3.497(0.0)$ & $3.466(0.0)$ & $3.367(0.0)$ & $3.135(0.0)$ \\
\hline
\end{tabular}

${ }^{1}$ Biodiversity indexes for repetitions of samples ( $\mathrm{n}=3$ ) estimated using Shannon's Diversity Index. $H=-\Sigma p_{\mathrm{i}} \ln p_{\mathrm{i}}$. Means $(\bar{x})$ and standard deviations (SD) are shown together with the diversity values.

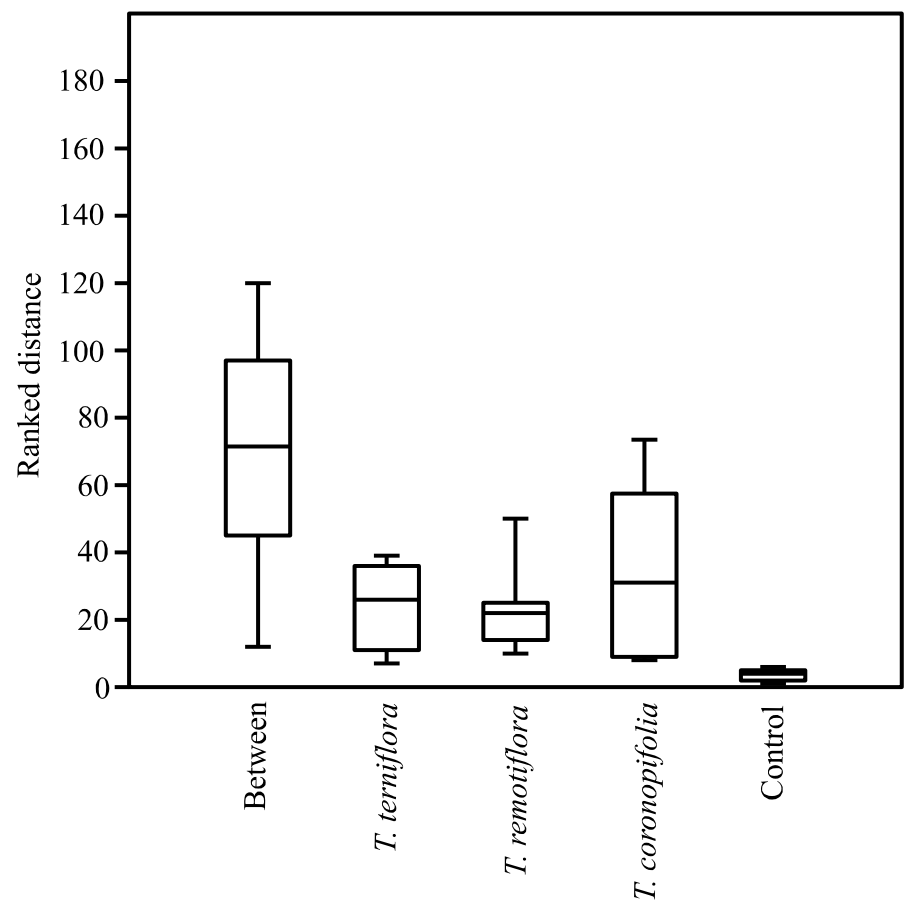

Figure 2. Boxplot of the mean Bray-Curtis distance measures of DGGE profiles obtained from rhizosphere soil samples of three species of the genus Tagetes

\section{nMDS analysis of DGGE banding patterns}

Analysis with a non-metric MDS ordination in two dimensions and Bray-Curtis similarity measure resulted in a stress value of 0.232 . However, adjustment for three dimensions produced a stress value of 0.179 , which allowed a better interpretation of the nMDS plot (Figure 3). This plot showed the separation of three groups of bacterial populations. The first was located at the top right and corresponds to the control samples. 
The second group was situated on the bottom right and includes the samples taken at 3, 30, 60 and 90 days of the species Tagetes coronopifolia. Finally, the overlapping groups of Tagetes terniflora and $T$. remotiflora were localized to the left of the graph. These results show that the bacterial communities of the control and three species of Tagetes differ clearly, as does $T$. coronopifolia with respect to the other two species.

\section{Analysis of similarities (ANOSIM)}

The one-way analysis of similarities (ANOSIM) showed significant differences between $T$. terniflora and $T$. coronopifolia (1-way ANOSIM $\mathrm{R}=0.78, \mathrm{p}<0.05$ ), between $T$. remotiflora and $T$. coronopifolia (1-way ANOSIM $\mathrm{R}=0.79, \mathrm{p}<0.05$ ), and between each species of Tagetes and the control (Table 2, Figure 2). The value of the one-way Global $\mathrm{R}$ for the three species of Tagetes was $\mathrm{R}_{\mathrm{Global}}=0.83$ at $p=<0.05$, which allowed us to reject the null hypothesis and demonstrate that the differences among species were significant. On the other hand, the Global $R$ for the factor time was $R_{\text {Global }}=-0.028$, and $p=>0.05$, so we were able to accept the null hypothesis of no significant differences with respect to sampling times. The PERMANOVA test showed a significant effect of the Tagetes species on the structure of the bacterial community $(\boldsymbol{F}=5.28 ; \boldsymbol{p}<0.01)$. Significantly, the greatest differences were found between $T$. cornopifolia and $T$. terniflora with $p=0.32 ; T$. cornopifolia and T. remotiflora with $p=0.026$; and $T$. coronopifolia and the control with $p$ $=0.029$. No significant differences were found with respect to time $(F=0.67, p=0.86)$.

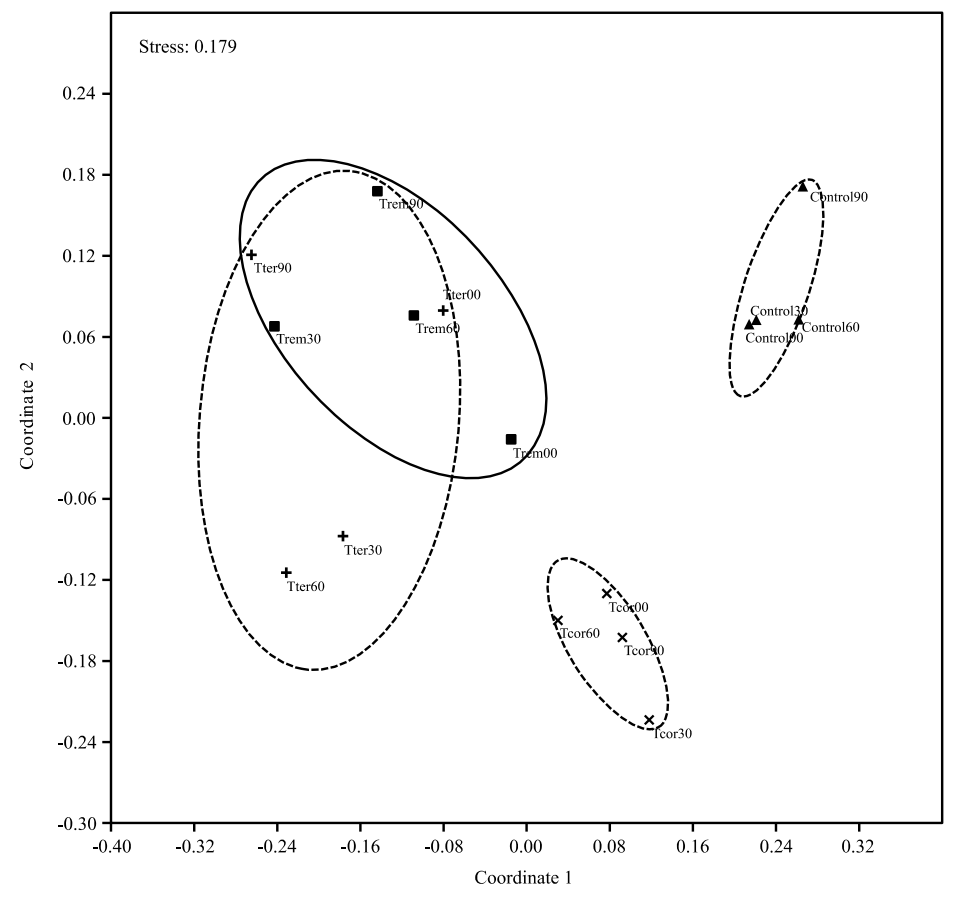

Figure 3. Two-dimensional plots of nMDS analyses from DGGE patterns to compare differences in bacterial communities taken from rhizosphere soil samples of three species of the genus Tagetes 


\section{Phylogenetic analysis}

Six bands from the DGGE profiles of rhizobacteria communities of $T$. terniflora, $T$. remotiflora and $T$. coronopifolia were selected for molecular identification. The criterion utilized in the selection of the bands was basically their atypical or discontinuous presence or absence at the different sampling times. Band B1 was present at 3 and 30 days, absent at 60 days, and reappeared at 90 days. Band B2 was absent at 3, 30 and 90 days, and only present at 60 days. Band B3 was present at 3 days but absent from the later samples taken at 30, 60 and 90 days. Band B4 was present on days 30 and 60, but absent at 3 and 90 days. Band B5 was present at 3 and 30 days, but absent at 60 and 90 days. Finally, Band B6 was absent at 3 and 30 days, but present at 60 and 90 days (Figure 1A).

Figure 4 shows a phylogenetic tree constructed on the basis of the band sequences obtained from the DGGE molecular profiles of the rhizobacteria communities from the soil samples of $T$. terniflora, $T$. remotiflora and $T$. coronopifolia. The phylogenetic analysis shows the relations of bands B1, B2, B4 and B5 to the group of the genus Pseudomonas; of band B3 to non-cultured bacteria; and of band B6 to microorganisms of the genus Delftia.

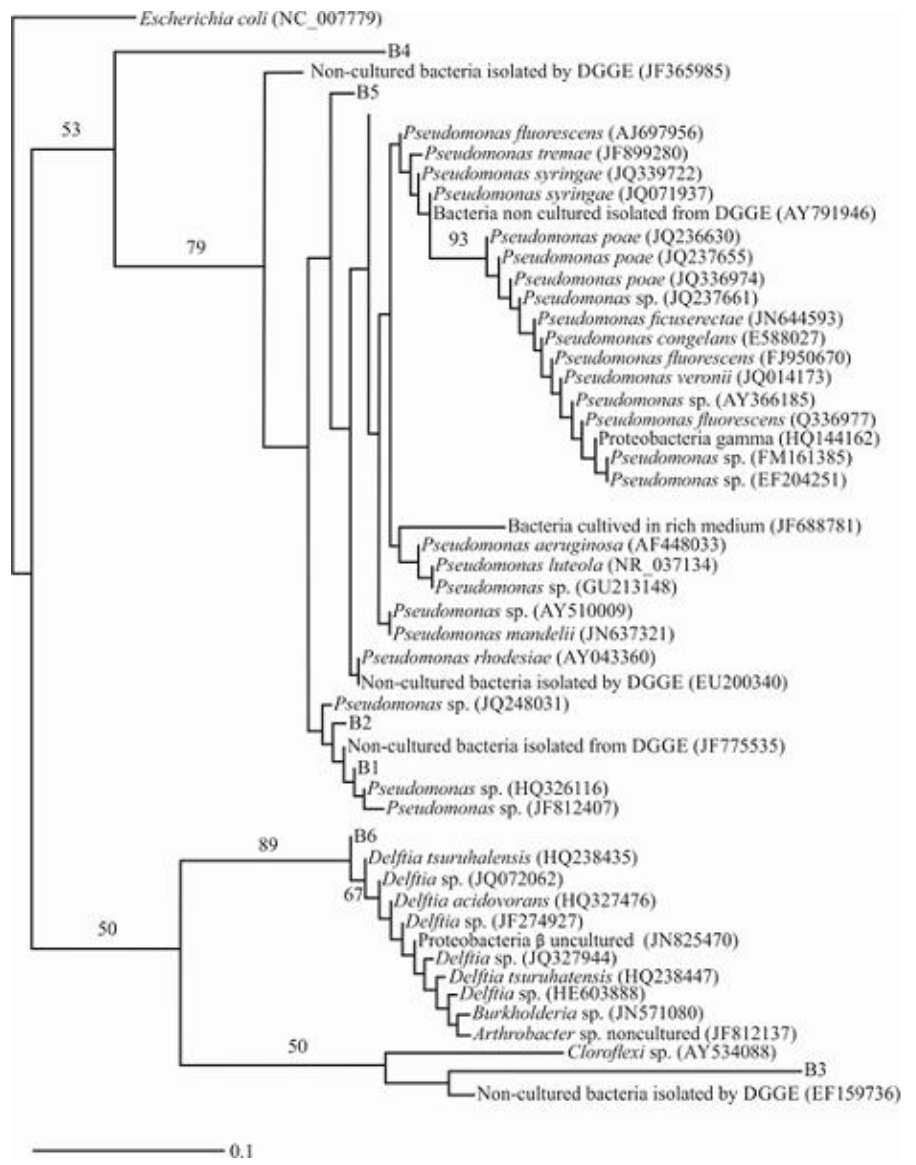

Figure 4. Phylogenetic tree constructed on the basis of the sequences from hypervariable region V5 of the $16 \mathrm{~S}$ rDNA of the bands of interest selected from the molecular profiles of the rhizospheric bacteria in T. terniflora (B1 and B2), T. coronopifolia (B3 and B4) and T. remotiflora (B5 and B6), generated by $D G G E$ 
Table 2. ANOSIM statistics of Bray-Curtis similarity measures $(R)$ from the rhizospheres of three species of the genus Tagetes and control

\begin{tabular}{l|c|c}
\hline \multicolumn{1}{c|}{ Rhizosphere } & Statistical R & $\boldsymbol{p}$ value \\
\hline T. terniflora vs. T. remotiflora & 0.38 & 0.086 \\
T. terniflora vs. T. coronopifolia & 0.78 & 0.026 \\
T. remotiflora vs. T. coronopifolia & 0.79 & 0.027 \\
T. terniflora vs. Control & 0.98 & 0.026 \\
T. remotiflora vs. Control & 1.00 & 0.031 \\
T. coronopifolia vs. Control & 0.79 & 0.027 \\
\hline
\end{tabular}

\section{Discussion}

The nature of the changes in structure and diversity of soil bacterial communities that result from the interactive effects of different plant species is a little-studied issue in Microbial Ecology. The use of techniques based on the Polymerase Chain Reaction (PCR) of metagenomic DNA coupled with Denaturalizing Gradient Gel Electrophoresis (DGGE) allow us to analyze the relative abundance of the populations of dominant bacteria and compare the successions or changes in the structure of microbial communities in environmental samples (Muyzer and Smalla, 1998; Brons and van Elsas, 2008; RodríguezLanetty et al., 2013; Chen et al., 2014). Although the usefulness of these techniques is limited by the number of DNA bands and the complexity of the profiles obtained (Nannipieri et al., 2003; Heuer et al., 2001; McCaig et al., 2001; Curtis et al., 2002), when employed over time, these DNA band profiles can help improve our understanding of the succession of microbial soil communities.

This study analyzed the effect of three species of Tagetes on the structure of bacterial communities in samples from rhizosphere at different times. These plants are recognized for their allelopathic action because their roots naturally exude components denominated $\alpha$ terthienyles (Meissner et al., 2013). The results presented here suggest a heterogeneity in the diversity of bacterial communities in the rhizosphere related with plant species. In spite of we failed to detect a selective sweep that leads to a drastic reduction in the alpha diversity estimated through Shannon index we were able to find a drastic change in the bacterial composition trough time.

In relation to the above mentioned results, several earlier studies have suggested a selective effect of microbial populations in plant rhizospheres driven by edaphological characteristics of the soil (Duineveld et al., 1998; Guong et al., 2012) an effect that is highly-specific and reproducible in several vegetable species (Kumar et al., 2016). Nevertheless, recent works have shown that changes in the microbial communities of the rhizosphere could be related with habitat filtering or intraspecific competition. For example, Shi et al. (2015) analyze the changes in microbial rhizosphere communities of the annual grass Avena fatua in two growing sessions and found that in spite of the different starting communities in both seasons, the successional patterns were similar and the final communities were very similar. On the other hand, Yuan et al. (2016) analyzed the rhizosphere of the seepweed Suaeda salsa and found that both phylogenetic clustering (abiotic factors) and overdispersion (biotic factors) are involved in the high tolerance to salinity in this plant species. 
The genus Tagetes has been characterized as exuding allelopathic compounds of the thiophenes type which have a nematocide function that has been demonstrated in both field and laboratory (Riga et al., 2005). Once isolated and purified, these allelochemical compounds have been used in vitro, where they have shown antiviral, antibacterial, antifungal and insecticide properties as well. Although many tests have demonstrated their allelochemical action, by determining the values of Shannon's diversity indexes obtained from sterilized agricultural soil (Table 1), the results of the present study demonstrate a possible selective, species-specific effect of plant rhizospheres on the microbial populations in the soil that develops through exudation during their developmental period as has been proposed in other plant species (Singh and Mukerji 2006; Chaparro et al., 2013).

Topp et al., (1998) analyzed the effect of the roots of Tagetes sp. on microbial communities in the soil. Their study considered the suppressor effect of the thiophenes, which are heterocyclic molecules with sulfur atoms that by activating $\alpha$-terthienyl produce oxygen-free radicals. In this perspective, if the roots of Tagetes sp. release a biocide that is activated in the soil, then the microbial populations of the rhizosphere of Tagetes sp. should be substantially perturbed. In an effort to demonstrate this, those researchers took measurements of the size of microbial populations and their activity in soils from fields and greenhouses where Tagetes sp had been cultivated, and compared them to soils from uncultivated yards (with no vegetation) and fields where rye had been planted (Secale cereale L.). The results obtained using extraction-fumigation methods to measure the microbial biomass (MB), epifluorescence microscopy (5-[4,6-dichlorotriazine-2- $\gamma 1]$ aminofluorescein) to quantify total bacteria, and heterotrophic bacterial plate counts with different media, the most probable number for the count of nitrifying bacteria demonstrated that the size of microbial populations and their activity in the diverse soils had no significant differences (Topp et al., 1998). Similar results have been found with other methods, such as marking the rye residues with ${ }^{14} \mathrm{C}$ and adding them to soils with the different treatments revealed mineralization activities that were slightly faster in the soil cultivated with rye than in the other treatments. In addition, measurements of the mortality rates of bacterial cells of Escherichia coli and Rhodococcus TE1 introduced into the soils cultivated with Tagetes sp. and the other treatments indicated that there was no accumulation of the biocides. These findings allowed the authors to conclude that the allelochemical exudates released by Tagetes sp. did not cause a general decline in the number of microorganisms in the soils and, possibly, that the control of nematodes by this plant might proceed through some other mechanism, and is not due to the release of a biocide into the soil. Analyses of the results of the BoxPlot graph (Figure 2), the DGGE gel (Figure 3A), and the dendrogram (Figure 3B) confirm the phenomenon of a specific, heterogeneous selection of bacterial populations by the species of the plant Tagetes.

The phylogenetic tree reveals the presence of three principle groups: the first made up of bacteria of the genus Delftia ( $\beta$-proteobacteria), the second of bacteria of the genus Pseudomonas ( $\gamma$-proteobacteria), and the third a non-cultured bacterium (Clorofexi). Shi et al. (2013) detected significant increases in the relative abundances of rhizobacterias in classes $\alpha$-proteobacteria, $\beta$-proteobacteria, and $\gamma$-proteobacteria, which are well known rhizosphere colonizers and have generally been characterized as fast-growing r-strategists, which respond positively to low-molecular-weight substrates abundant in plant root exudates. 
The population succession obtained using DGGE demonstrated that bands B1 (3 days, $T$. terniflora), B2 (60 days, T. terniflora), B4 (30 days, T. remotiflora) and B5 (60 days, $T$. coronopifolia) were variably present at the different times analyzed (Figure 3A), while the phylogenetic analysis indicated that these sequenced bands are found in the group of bacteria belonging to the genus Pseudomonas. BLAST analysis also demonstrated that all the sequences related to the genus Pseudomonas had high similarities to species of Pseudomonas isolated from rhizospheric and other environments.

Some species of the genus Pseudomonas are often described as plant-growth promoting rhizobacteria (PGPR), due to the fact that they interact with the roots of plants to produce antibiotics, phytohormones, HCN, and siderophores that promote development and protect them from pathogenic microorganisms (Upadhyay and Srivastava, 2010; Subramanian and Saytan, 2014). In this way, together with the use of such techniques as electronic microscopy and genetically-marked strains, studies have shown that the mutual relations entailed in the spatial distribution of the genus Pseudomonas are not uniform in the roots of plants, because they prefer to inhabit regions characterized by a higher release of exudation, such as the unions between the epidermal cells of the root, indented parts of the epidermis, or lateral sites on the roots (Chin-A-Woeng et al., 1997; Fukui et al., 1994). On the other hand, observations have also shown that other bacteria -such as Rhizobium-prefer the tips of root hairs (Smit et al., 1986; Smit et al., 1987), presumably due to the presence of specific receptors (Swart et al., 1994).

Specific studies of the genus Pseudomonas have demonstrated their isolation at high frequencies from soils that suppress black rot in the roots of tobacco plants (Thielaviopsis basicola) and most of the fungal diseases that affect wheat (Gaeumannomyces graminis var. Tritici). This suppression phenomenon in soils is now well-characterized, and there is strong evidence to indicate that it is the result of the release of the antifungal metabolite 2, 4-diacetilflouroglucinol (PHL) (Walsh et al., 2001). Maize is another crop whose roots promote the colonization of antagonistic groups of Pseudomonas, and microbiological quantification has shown that a high proportion $(\sim 15 \%)$ of the strains of Pseudomonas isolated from the rhizoplane contain genes for the biosynthesis of PHL, while nonrhizospheric soils present low levels of this gene $(<0.65 \%)$ (Picard et al., 2000).

However, in the case of antagonistic plants of the genus Tagetes, mutual relationships seem to be more complex, since previous studies have reported the presence and exudation of essential oils with distinct compositions that were common to different species of this genus (Lawrence, 1985; Héthélyi et al., 1986; Marotti et al., 2004). The most remarkable characteristic of the metabolites produced by the genus Tagetes is that they have toxic activity on various microorganisms that are pathogenic to plants, animals (Eguaras et al., 2005) and humans (Cestari et al., 2004). Therefore, this genus is a potential option for use in agriculture and medicine as a natural supplier of biocides, biorepellents, or biostatic effects (Díaz-Cedillo and Serrato-Cruz, 2011).

Band B3 is similar to the group of non-cultured bacteria of the genus Clorofexi. A recent study (Krzmarzick et al., 2012) demonstrated that in terrestrial environments this genus naturally utilizes organochlorine compounds as final electron-accepters. It is a well-known fact that plants, marine organisms, insects, bacteria, fungi and mammals all naturally produce organochlorine compounds (Öberg, 2002; Öberg and Sandén 2005; Krzmarzick et al., 2012), and this has helped us to better understand that in terrestrial environments the 
transformation of chlorides into organochlorine compounds occurs through the activity of the enzyme chloroperoxidase that results in levels of organochlorine compounds that tend to be higher than those of chloride on the soil surface. As soil depth increases, changes in the speciation of chlorine take place, predominantly from organic-to-inorganic. This suggests that the organochlorines that exist naturally in the organic matter of the soil may be subjected to such biogeochemical processes of chlorination (Krzmarzick et al., 2012).

In the case of plants of the genus Tagetes, some 126 secondary metabolites have been identified with diverse carbon skeletons, including the thiophenes, of which 5-(but-l-chloro2-ol-3-ynyl)-2,2'-bithienyl is characterized as containing a chlorine atom in its $\mathrm{R} 2$ (Xu et al., 2012). However, the presence of Band B3 at 3 days after transplanting the Tagetes seedlings (time $=3$ days) and its subsequent disappearance in the DGGE profiles raises several questions concerning the ecological functions and symbiotic relations between plants and microorganisms.

Finally, the sequence of nucleotides in Band B6 was similar to the group of bacteria of the genus Delftia, which has been characterized by its role and capacity to produce Damino acids in the hemolymph of an insect called the glassy-winged sharpshooter (GWSS) (Bextine et al., 2010). Also, Delftia sp., together with other bacteria, such as Arthrobacter ureafaciens, Phyllobacterium myrsinacearum and Rhodococcus erythropolis, have been identified as phosphate-solubilizing bacteria (PSB), thus confirming their ability to solubilize significant amounts of tricalcium phosphate through secretion of organic acids (Chen et al., 2006; Saharan and Nehra, 2011).

Although this band was only observed at 60 and 90 days and exclusively in the rhizosphere of $T$. coronopifolia, this does not preclude its possible existence in the other species of Tagetes. Its presence at these times could suggest an association with the process of floral initiation. Serrato-Cruz et al. (1998) determined that floral initiation of T. patula and $T$. erecta occurs 56 days after planting, and various studies have reported the use of experimental microorganisms and commercial isolates from rhizospheric soils that have the capacity to solubilize phosphates which positively promote the onset of flowering and an increase in the diameter and length of the flower in ornamental plants such as tuberoses (nardo) (Swaminathan et al., 1999), roses (Singh et al., 2003), carnations (Gupta et al., 2004), gladioli (Muzain et al., 2004), gaillardias (Deshmukh et al., 2008), and some varieties of African marigolds (Chandrikapure et al., 1999).

\section{Conclusions}

This investigation is a preliminary attempt to study the antagonistic effect of three species of the genus Tagetes in the bacterial communities of the rhizosphere. We found no changes in alpha diversity but a drastic change in Beta diversity trough time and among the three species of the genus Tagetes. The results presented herein support the selective effect of plant rhizospheres on microbial populations in the soil; an effect that can be highlyspecific due that even within Tagetes each single species had a unique bacterial community. It is necessary in the future to perform experiments of rhizobacterial succession that imply other molecular techniques and quantification of the allelochemicals exuded by the roots and physicochemicals properties of the soil at different stages of plant development to 
evaluate if the community structure is driven by biotic or abiotic factors. The results found in this study could be an important finding due that it makes possible to determine and establish the optimum time for the application of biological controls or biofertilizers on commercial plants.

Acknowledgments. This study was financed by the Programa de Mejoramiento del Profesorado (PROMEP) through Apoyo de Fomento a la Generación y Aplicación Innovadora del Conocimiento (UPPACH-PTC079). The authors are also extremely grateful to Dr. Miguel Angel Serrato Cruz for providing the marigold seed included in this work and to Dra. Carla Centeno and Paul Kersey for the kindly review of the translated manuscript.

\section{REFERENCES}

[1] Bextine, B., Craig, L., Hail, D., Dowd, S. E. (2010): Hemolymph-associated symbionts. - In: Esser, T., West, D. (Eds.) Identification of Delftia sp. glassy-winged sharpshooters and investigation into their putative function. Pierce's Disease. Research Symposium, 13-15.

[2] Brons, J. K., van Elsas, J. D. (2008): Analysis of bacterial communities in soil by use of Denaturing Gradient Gel Electrophoresis and clone libraries, as influenced by different reverse primers. - Applied and Environmental Microbiology 74(9): 2717-2727.

[3] Centeno, C. M., Mejía, O., Falcón, L. I. (2016): Habitat conditions drive phylogenetic structure of dominant bacterial phyla of microbialite communities from several locations in Mexico. - Revista de Biología Tropical 64 (3).

[4] Cestari, I. M., Sarti, S. J., Waib, C. M., Castello, A. (2004): Evaluation of the potential insecticide activity of Tagetes minuta (Asteraceae) essential oil against the head lice Peduncularis humanus capilis (Phthiraptrea; Pediculidae). - Neotropical Entomology 33: 805-807.

[5] Chandrikapure, K. R., Sadawarte, D. M., Panchabh, B. D. (1999): Effect of bioinoculants and graded doses of nitrogen on growth and flower yield of marigold (Tagetes erecta L.). - The Orissa Journal of Horticulture 27 (2): 31-34.

[6] Chaparro, J. M., Badri, D. V., Bakker, M. G., Sugiyama, A., Manter, D. K., Vivanco, J. M. (2013): Root exudation of phytochemicals in Arabidopsis follows specific patterns that are developmentally programmed and correlate with soil microbial functions. - PLoS One 8: e55731.

[7] Chiarini, L., Bevivino, A., Tabacchioni, S. (1994): Factors affecting the competitive ability in rhizosphere colonization of plant-growth promoting strains of Burkholderia cepacia. - In: Ryder, M. H., Stephens, P. M., Bowen, G. D. (Eds.) Proceedings of the Third International Workshop on Plant Growth-Promoting Rhizobacteria. - CSIRO, Australia, Adelaide, Australia, 204-206.

[8] Chen, M., Li, X., Yang, Q., Chi, X., Pan, L., Chen, N., Yang, Z., Wang, T., Wang, M., Yu, S. (2014): Dynamic succession of soil bacterial community during continuous cropping of peanut (Arachis hypogaea L.). - PLoS One 9 (7).

[9] Chen, Y. P., Rekha, P. D., Arun, A. B., Shen, F. T., Lai, W. A., Young, C. C. (2006): Phosphate solubilizing bacteria from subtropical soil and their tricalcium phosphate solubilizing abilities. - Applied Soil Ecology 34: 33-41.

[10] Chin-A-Woeng, T. F. C., de Priester, W., van der Bij, A. J., Lugtenberg, B. J. J. (1997): Description of the colonization of a gnotobiotic tomato rhizosphere by Pseudomonas 
fluorescens biocontrol strain WCS365 using scanning electron microscopy. - Molecular Plant-Microbe Interactions 10:79-86.

[11] Crits-Christoph, A., Robinson, C. K., Barnum, T., Fricke, W. F., Davila, A. F., Jedynak, B., McKay, C. P., DiRuggiero, J. (2013): Colonization patterns of soil microbial communities in the Atacama Desert. - Microbiome 1 (1): 28.

[12] Curtis, T. P., Sloan, W. T., Scannell, J. W. (2008): Estimating prokaryotic diversity and its limits. - Proceedings of the National Academic Sciences USA 99:10494-10499.

[13] Deshmukh, P. G., Khiratkar, S. D., Badge, S. A., Bhongle, S. A. (2008): Effect of bioinoculants with graded doses of NPK on growth and yield of gaillardia. - Journal of Soils and Crops 18 (1): 212-216.

[14] Díaz-Cedillo, F., Serrato-Cruz, M. A.(2011): Composition of Tagetes parryi A. Gray essential oil. - Revista Fitotecnia Mexicana. [online] 34 (2): 145-148.

[15] Di Cello, F., Bevivino, A., Chiarini, L., Fani, R., Paffetti, D., Tabacchioni, S., Dalmastri, C. (1997): Biodiversity of a Burkholderia cepacia population isolated from the maize rhizosphere at different plant growth stages. - Applied and Environmental Microbiology 63:4485-4493.

[16] Duineveld, B. M., Kowalchuk, G. A., Keizer, A., Van Elsas, J. D., Van Veen, J. A. (2001): Analysis of the bacterial communities in the rhizosphere of chrysanthemum via denaturing gradient gel electrophoresis of PCR amplified 16S ribosomal RNA and DNA fragments. Applied and Environmental Microbiology 67: 172-178.

[17] Eguaras, M. J., Fuselli, S., Gende, L., Fritz, R., Ruffinengo, S. R., Clemente, G., González, G., Bailac, P. N., Ponzi, M. I. (2005): An in vitro evaluation of Tagetes minuta essential oil for the control of the honeybee pathogens Paeniibacillos larvae and Ascosphaera apis, and the parasitic mite Varroa destructor. - Journal of Essential Oil Research 17: 336-340.

[18] Fukui, R., Poinar, E. I., Bauer, P. H., Schroth, M. N., Hendson, M., Wang, X-L., Hancock, J. G. (1994): Spatial colonization patterns and interaction of bacteria on inoculated sugar beet seed. - Phytopathology 84: 1338-45.

[19] Guindon S, Dufayard J-F, Lefort V, Anisimova M, Hordijk W, Gascuel1 O. New algorithms and methods to estimate Maximum-Likelihood phylogenies: Assessing the Performance of PhyML 3.0. - Systematic Biology. 2010; 59 (3): 307-321.

[20] Guong, V. T., Rosling, A., Alström, S., Chai, B., Högberg, N. (2012): Different crop rotation systems as drivers of change in soil bacterial community structure and yield of rice, Oryza sativa. - Biology and Fertility Soils 48: 217-225.

[21] Gupta, Y. C., Suman, B., Sharma, Y. D., Thakur, R., Ritu, J. (2004): Effect of growing media and fertilization on growth and flowering of carnation (Dianthus caryophyllus L.) under protected conditions. - National Symposium on Recent Trends and Future Strategies in Ornamental Horticulture, 2004: 77.

[22] Guzmán-Plazola, R. A., Hernández-Flores, B., Franco-Navarro, F., Cadena-Hinojosa, M. (2008): Nemátodos agalladores de la Vega de Metztitlán, Hidalgo, México: Identificación, distribución especial y relación con factores edáficos. - Nematropica 38: 47-61.

[23] Hamlen, R., Lukezic, F., Bloom, J. (1972): Influence of age and stage of development on the neutral carbohydrate components in root exudates from alfalfa plants grown in a gnotobiotic environment. - Canadian Journal of Plant Science 52: 633-642.

[24] Hammer, Ø., Harper, D. A. T., Ryan, P. D. (2001): PAST: Paleontological statistics software package for education and data analysis. - Palaeontologia Electronica 4: 9. http://palaeoelectronica.org/2001_1/past/issue1_01.htm.

[25] Hardoim, P. R., van Overbeek, L. S., Berg, G., Pirttilä, A. M., Compant, S., Campisano, A., Döring, M., Sessitsch, A. (2015): The Hidden World within Plants: Ecological and 
Evolutionary Considerations for Defining Functioning of Microbial Endophytes. Microbiology and Molecular Biology Reviews: MMBR 79 (3): 293-320.

[26] Héthélyi, É., Dános, B., Tétényi, P., Koczka, I. (1986): GC/MS analysis of the essential oils of some Tagetes species. - In: Brunke, E. S. (ed.) Progress in Essential Oil Research. Walter de Gruyter \& Co. Berlin, Germany, 131-137.

[27] Heuer, H., Wieland, G., Schonfeld, J., Schnwalder, A., Gomes, N. C. M., Smalla, K. (2001): Bacterial community profiling using DGGE or TGGE analysis. - In: Rochelle, P. A. (ed.) Environmental Molecular Microbiology: Protocols and Applications, Horizon Scientific Press, Wynmondham, UK., 177-190.

[28] Hooks, C. R. R., Wang, K-H., Ploegc, A., McSorley, R. (2010): Using marigold (Tagetes spp.) as a cover crop to protect crops from plant-parasitic nematodes. - Applied Soil Ecology 46: 307-320

[29] Johnson, M. J., Lee, K. Y., Scow, K. M. (2003): DNA fingerprinting reveals links among agricultural crops, soil properties, and the composition of soil microbial communities. Geoderma 114 (3-4): 279-303.

[30] Kirk, J. L., Beaudette, L. A., Hart, M., Moutoglis, P., Klironomos, J. N., Lee, H., Trevors, J. T. (2004): Methods of studying soil microbial diversity. - Journal of Microbiological Methods 58: 169-188.

[31] Krzmarzick, M. J., Crary, B. B, Harding, J. J, Oyerinde, O. O., Leri, A. C., Myneni, S. C. B., Novak, P. J. (2012): Natural niche for organohalide-respiring Chloroflexi. - Applied and Environmental Microbiology 78 (2): 393-401.

[32] Kumar, M., Männistö, M. K., van Elsas, J. D., Nissinen, R. M. (2016): Plants impact structure and function of bacterial communities in Arctic soils. - Plant Soil 399: 319.

[33] Lawrence, B. M. (1985): Essential oils of the Tagetes genus. - Perfume \& Flavour 10: 73-82.

[34] Legendre, P., Legendre, L. (2012): Numerical Ecology, 3rd English edn. - Elsevier Science BV, Amsterdam.

[35] Marotti, M., Piccaglia, R., Biavati, B., Marotti, I. (2004): Characterization and yield evaluation of essential oils from different Tagetes species. - Journal of Essential Oil Research 16: 440-444.

[36] McCaig, A. E., Glover, L.A., Prosser, J. L. (2001a): Numerical analysis of grassland bacterial community structure under different land management regimens by using $16 \mathrm{~S}$ ribosomal DNA sequence data and denaturing gradient gel electrophoresis banding patterns. - Applied and Environmental Microbiology 67:4554-4559.

[37] Meissner, R., Nel, P. C., Beyers, E. A. (1986):Allelopathic influence of Tagetes and Bidensinfested soils on seedling growth of certain crop species. - South African Journal of Plant and Soil 3 (4): 176-180.

[38] Muyzer, G., de Waal, E. C., Uitterlinden, A. G. (1993): Profiling of complex microbial populations by denaturing gradient gel electrophoresis analysis of polymerase chain reactionamplified genes coding for 16S rRNA. - Applied and Environmental Microbiology 59 (3): 695-700.

[39] Muyzer, G., Smalla, K. (1998): Application of denaturing gradient gel electrophoresis (DGGE) and temperature gradient gel electrophoresis (TGGE) in microbial ecology. Antonie van Leeuwenhoek., Int. J. G. 73:127-141.

[40] Muzain, M., Singh, D. B., Muruli, Y., Rashmi, C. (2004): Effects of different biofertilizer on vegetative growth, spike yield and corn production of gladiolus Cv. 'Snow Princes'. - In: Reddy, B. S., Janakiram, T., Kulkarni, B. S. and Narayanaswamy, P. (Eds.) National Symposium on Recent Trends and Future Strategies in Ornamental Horticulture, 1-4.

[41] Nannipieri, P., Ascher, J., Ceccherini, M. T., Landi, L., Pietramellara, G., Renella, G. (2003): Microbial diversity and soil functions. - European Journal of Soil Science 54: 655-670. 
[42] Nivsarkar, M., Bapu, C. B., Padh, H. (2001): Alpha-terthienyl: A plant-derived new generation insecticide. - Current Science India 81 (6): 667-672.

[43] Öberg, G. (2002): The natural chlorine cycle fitting the scattered pieces. - Applied Microbiology and Biotechnology 58 (5): 565-581.

[44] Öberg, G., Sandén, P. (2005): Retention of chloride in soil and cycling of organic matter bound chlorine. - Hydrological Processes 19: 2123-2136.

[45] Petersen, S. O., Nielsen, T. H., Frostegărd, Å., Olesen, T. (1996): O2 uptake, C metabolism and denitrification associated with manure hot-spots. - Soil Biology and Biochemistry 28: 341-349.

[46] Picard, C., Di Cello, F., Ventura, M., Fani, R., Guckert, A. (2000): Frequency and biodiversity of 2,4-diacetylphloroglucinol-producing bacteria isolated from the maize rhizosphere at different stages of plant growth. - Applied and Environmental Microbiology 66: 948-955.

[47] Pinton, R., Varanini, Z., Nannipieri, P. (2001): The Rhizosphere: Biochemistry and Organic Substances at the Soil-Plant Interface. - Marcel Dekker, New York.

[48] Pontarp, M., Canbäck, B., Tunlid, A., Lundberg, P. (2012): Phylogenetic analysis suggests that habitat filtering is structuring marine bacterial communities across the globe. - Microbial Ecology 64 (1): 8-17.

[49] Posada, D., Crandall, K. A. (1998): MODELTEST: testing the model of DNA substitution. Bioinformatics 14 (9): 817-818.

[50] Prosser, I. J. (2002): Molecular and functional diversity in soil micro-organisms. - Plant and Soil 244: 9-17.

[51] Ranjard, L., Dequiedt, S., Jolivet, C., Saby, N. P. A., Thioulouse, J., Harmand, J., Loisel, P., Rapaport, A., Fall, S., Simonet, P., Joffre, R., Bouré, N., Chemidlin-Prévost, B., Maron, P-A., Mougel, C., Martin, M. P., Toutain, B., Arrouays, D., Lemanceau, P. (2010): Biogeography of soil microbial communities: a review and a description of the ongoing french national initiative. - Agronomy for Sustainable Development 30: 359-365.

[52] Riga, E., Hooper, C., Potter, J. (2005): In vitro effect of marigold seed exudates on plant parasitic nematodes. - Phytoprotection 86: 31-35

[53] Rodríguez-Lanetty, M., Granados-Cifuentes, C., Barberan, A., Bellantuono, A. J., Bastidas, C. (2013): Ecological inferences from a deep screening of the complex bacterial consortia associated with the coral, Porites astreoides. - Molecular Ecology 22: 4349-4362.

[54] Rovira, A. (1965): Plant root exudates and their influence upon soil microorganisms. - In Baker, K. F., Snyder, W. C. (ed.) Ecology of soil-borne plant pathogens prelude to biological control. University of California Press, Berkeley. 170.

[55] Saharan, B. S., Nehra, V. (2011): Plant Growth Promoting Rhizobacteria: A Critical Review. - Life Sciences and Medicine Research LSMR-21.

[56] Serrato-Cruz, M. A., Grimaldo-Juárez, O., González-Hernández, V. A. (1998): Análisis de crecimiento y evolución bajo domesticación en dos especies de cempoalxóchitl (Tagetes erecta y Tagetes patula). - Revista Chapingo Serie Horticultura 4 (2): 75-82.

[57] Shi, S., Nuccio, E., Herman, D. J., Rijkers, R., Estera, K., Li, J., Nunes Da Rocha, U., Zhill, H., Pett-Ridge, J., Brodle, E. L., Zhou, J., Firestone, M. (2015): Successional trajectories of rhizosphere bacterial communities over consecutive seasons. - Mbio. 6 (4): e00746-15.

[58] Singh, A. K., Ashutosh, K. M., Rajesh, S., Yeshpal, S. (2003): Effect of organic and inorganic sources of nutrients on flowering attributes in rose. - Progressive Horticulture 35 (1): 78-81.

[59] Singh, G., Mukerji, K. G. (2006): Root exudates as determinant of rhizospheric microbial biodiversity. - In: Mukerji, K. G., Manoharachary, C., Singh, J. (eds.) Microbial activity in the rhizosphere. Springer, Berlin, Germany, 39-54. 
[60] Smit, G., Kijne, J. W., Lugtenberg, B. J. J. (1986): Correlation between extracellular fibrils and attachment of Rhizobium leguminosarum to pea root hair tips. - Journal of Bacteriology 168: 821-27.

[61] Smit, G., Kijne, J. W., Lugtenberg, B. J. J. (1987): Both cellulose fibrils and a Ca dependent adhesin are involved in the attachment of Rhizobium leguminosarum to pea root hair tips. Journal of Bacteriology 169: 4294-4301.

[62] Subramanian, J., Satyan, K. (2014): Isolation and selection of fluorescent pseudomonads based on multiple plant growth promotion traits and siderotyping. - Chilean Journal of Agricultural Research [online] 74 (3).

[63] Swaminathan, V., Ramaswamy, N., Pallia, O. A. (1999): Effect of Azospirillum, phoshobacteria and inorganic nutrients on the growth and yield of tuberose. - South Indian Horticulture 47 (1-6): 331-334.

[64] Swart, S., Logman, T. J. J., Lugtenberg, B. J. J., Kijne, J. W. (1994): Purification and partial charactization of a glycoprotein from pea (Pisum sativum) with receptor activity for rhicadhesin, an attachment protein of Rhizobiacea. - Plant Molecular Biology 24: 171-83.

[65] Tereschuk, M. L., Riera, M. V. Q., Castro, G. R., Abdala, L. R. (1997): Antimicrobial activity of flavonoids from leaves of Tagetes minuta. - Journal of Ethnopharmacology 56: 227-232.

[66] Thompson, J. D., Gibson, T. J., Higgins, D. G. (2002): Multiple Sequence Alignment Using ClustalW and ClustalX. - Current Protocols in Bioinformatics 00:2.3:2.3.1-2.3.22.

[67] Tomova, B. S., Waterhouse, J. S., Doberski, J. (2005): The effect of fractionated Tagetes oil volatiles on aphid reproduction. - Entomologia Experimentalis et Applicata 115: 153-159.

[68] Topp, E., Millar, S., Bork, H., Welsh, M. (1998): Effects of marigold (Tagetes sp.) roots on soil microorganisms. - Biology and Fertility of Soils 27: 149-154.

[69] Upadhyay, A., Srivastava, S. (2010): Evaluation of multiple plant growth promoting traits of an isolate of Pseudomonas fluorescens strain Psd. - Indian Journal of Experimental Biology 48: 601-609.

[70] Walsh, U. F., Morrissey, J. P., O’Gara, F. (2001): Pseudomonas for biocontrol of phytopathogens: from functional genomics to commercial exploitation. - Current Opinion in Biotechnology 12: 289-295.

[71] Weidenhamer, J. F., Boes, P. D., Wilcox, D. S. (2009): Solid-phase root zone extraction (SPRE): a new methodology for measurement of allelochemical dynamics in soil. - Plant and Soil 322: 177-186.

[72] Xu, L-W., Chen, J., Qi, H-Y., Shi, Y-P. (2012): Phytochemicals and their biological activities of plants in Tagetes L. - Chinese Herbal Medicines 4 (2): 103-117.

[73] Yuan, Z., Druzhinina, I. S., Labbé, J., Redman, R., Qin, Y., Rodriguez, R., Zhang, C., Tuskan, G. A., Lin, F. (2016): Specialized microbiome of a halophyte and its role in helping non-host plants to withstand salinity. - Scientific Reports 6: 32467.

[74] Zelezniak, A., Andrejev, S., Ponomarova, O., Mende, D. R., Bork, P., Patil, K. R. (2015): Metabolic dependencies drive species co-occurrence in diverse microbial communities. Proceedings of the National Academy of Sciences 112 (20): 6449-6454. 